\title{
Effect of salcatonin given intranasally on early postmenopausal bone loss
}

\author{
Kirsten Overgaard, Bente Jien Riis, Claus Christiansen, Marc A Hansen
}

Abstract

Objective-To study the effect of salmon calcitonin (salcatonin) given intranasally on calcium and bone metabolism in early postmenopausal women.

Design-Double blind, placebo controlled, randomised group comparison.

Setting-Outpatient clinic for research into osteoporosis.

Subjects-52 Healthy women who had had a natural menopause two and a half to five years previously.

Interventions-The 52 women were allocated randomly to two years of treatment with either salcatonin $100 \mathrm{IU}$ given intranasally $(n=26)$ or placebo $(n=26)$. Both groups received a calcium supplement of $500 \mathrm{mg}$ daily. Seven of the women receiving salcatonin and six of those receiving placebo left the study before its end.

Main outcome measures-Bone mineral content in the spine, the total skeleton, and the forearms after two years of treatment.

Results-Bone mineral content in the spine was significantly higher in the women who had received salcatonin than in those who had received placebo both after one year and after two years of treatment. After one year the difference was $3.8 \%$ (95\% confidence interval 0.0 to $7.6 \%$ ) and after two years it was $8.2 \%(3.8$ to $12.6 \%)$. In contrast, the bone mineral content in the distal and proximal forearms and in the total skeleton declined similarly in both groups by about $2 \%$ each year, and after two years of treatment the differences between the groups were not significant. Biochemical estimates of bone turnover were not affected by salcatonin.

Conclusion-The results suggest that salcatonin given intranasally in the dose used prevents bone loss in the spine of early post menopausal women but does not affect the peripheral skeleton. /,

\section{Introduction}

Oestrogen is generally accepted as effective prophylaxis against postmenopausal bone $\operatorname{loss}^{12}$ and osteoporosis. ${ }^{3+}$ This effect may be mediated partly by calcitonin as women receiving treatment with oestrogen have raised plasma calcitonin concentrations. ${ }^{56}$ Not all studies, however, have found a relation between calcitonin and oestrogen. ${ }^{78}$ Calcitonin, a peptide hormone produced in the parafollicular cells of the thyroid, is implicated in calcium homoeostasis by inhibiting bone resorption through a direct action on osteoclasts. ${ }^{9}$ It has therefore been used to treat diseases of calcium metabolism that are characterised by increased turnover of bone, such as Paget's disease and osteoporosis. $^{10}$

Calcitonin has until recently been available only as an injection, but a nasal spray has now been developed. We showed recently that salmon calcitonin (salcatonin) given intranasally is effective in treating established postmenopausal osteoporosis. " The rate of bone loss, however, is much faster during the early postmenopausal years. The question is, therefore, whether salcatonin is a valuable alternative to oestrogen in prophylaxis against postmenopausal osteoporosis. Results of preliminary studies indicate that salcatonin given both intranasally and by injection prevents early postmenopausal bone loss in the lumbar spine. ${ }^{1213}$

The aim of the present double blind, placebo controlled study was to examine the long term effect of salcatonin given intranasally on early postmenopausal bone loss in the spine, the forearm, and the total skeleton.

\section{Methods}

DESIGN OF STUDY

The study comprised 52 women aged 47-56 who had had a natural menopause two and a half to five years previously. The selection procedure, described in detail elsewhere, ${ }^{14}$ was as follows: a total of 9836 women aged 45 to 54 were sent questionnaires eliciting information about their last vaginal bleeding, gynaecological operations, and intake of drugs; 7484 questionnaires were returned. In all 558 women fulfilled the primary entry criteria - that is, their menstrual bleeding had stopped spontaneously within the previous six months to three years and they had not taken any sex hormones or other drugs known to influence calcium metabolism after the menopause. These women were invited to a meeting, and 397 attended. After being informed thoroughly about the trial 293 gave their consent to participate (according to the Helsinki Declaration II). All of them had a medical examination, and 270 fulfilled the secondary inclusion criteria - that is, they did not have any diseases known to influence calcium metabolism. They participated in a two year investigation of several prophylactic treatments for osteoporosis during which the 52 women in the present study received placebo or placebo-like drugs. ${ }^{15}$

After this first study ended we used random sampling numbers to allocate the 52 women to receive active drug $(n=26)$ or placebo $(n=26)$, both of which were distributed in sealed envelopes. None of the doctors, technicians, or patients knew whether the drug given was calcitonin or saline solution. Active treatment was salcatonin $100 \mathrm{IU}$ given intranasally (50 IU in the morning and $50 \mathrm{IU}$ at night) and calcium $500 \mathrm{mg}$ daily; placebo was saline solution and calcium $500 \mathrm{mg}$ daily. We examined the women every three months over the two years of the study.

\section{COMPLIANCE}

Of the 52 women, $39(75 \%)$ completed the two years of the study. Seven of the women receiving salcatonin left the study: two because of climacteric symptoms 


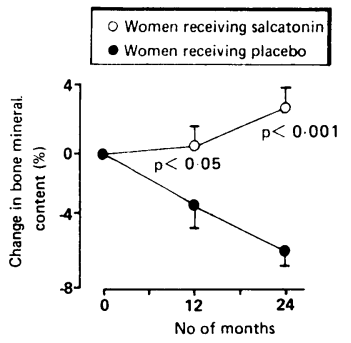

FIG 1-Mean (SEM) changes in bone mineral content in lumbar spine over two years in postmenopausal women treated with salcatonin $(n=19)$ or placebo $(n=20)$

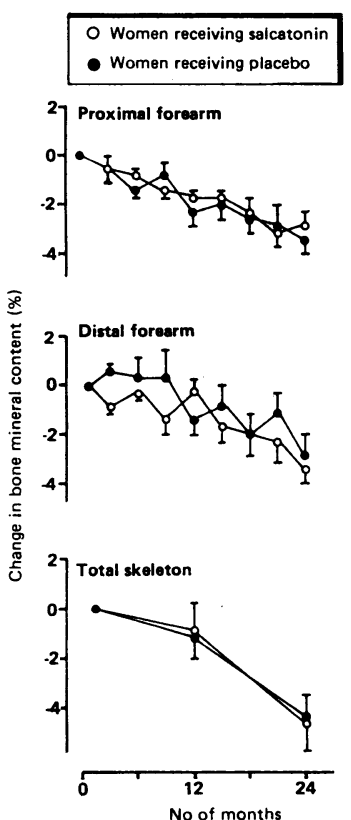

FIG 2-Mean (SEM) changes in bone mineral content in proximal forearm, distal forearm, and total skeleton over two years in postmenopausal women treated with salcatonin $(n=19)$ or placebo $(n=20)$ that required treatment with oestrogen; four because of lack of time; and one because of illness unrelated to the treatment. Six of the women receiving placebo left the study: one because of climacteric symptoms that required treatment with oestrogen; two because of lack of time; two because of intercurrent illness; and one because she went abroad. This left 19 women receiving salcatonin and 20 receiving placebo. As 10 of the 13 women who left the study did so at three months they were not included in the calculations.

\section{MEASUREMENT OF BONE MASS}

We measured the bone mineral content of the women's forearms every three months by single photon absorptiometry with a source of iodine-125 (3.7 GBq) with a photopeak at $27 \mathrm{keV}$. The method determines the bone mineral content in the proximal and the distal regions, which have estimated trabecular bone contents of $13 \%$ and $55 \%$, respectively. ${ }^{16}$ In our department the long term precision of the technique in vivo is $1 \%$ for the proximal region and $1.5 \%$ for the distal region. ${ }^{17}$

The bone mineral content of the lumbar spine was measured by dual photon absorptiometry with a DP3 scanner (Lunar Radiation) with a source of gadolinium-153 (37 GBq) with photopeaks at 44 and $100 \mathrm{keV}$. We calculated the spinal bone mineral content in vertebrae $\mathrm{L}_{2}$ to $\mathrm{L}_{4}$, including the intervertebral discs. The long term precision for this procedure in vivo is $3 \cdot 4 \% .^{17}$ The results were corrected for errors caused by relocating the source.

The bone mineral content of the total skeleton was also measured by dual photon absorptiometry with $a^{153} \mathrm{Gd}$ source ( $37 \mathrm{GBq}$ ) on a whole body scanner that was developed in our laboratory. The precision of this method is $2 \% .^{18}$ The trabecular bone contents of the lumbar spine and the total skeleton, measured by dual photon absorptiometry, are roughly $60 \%$ and $20 \%$, respectively. ${ }^{19}$ Spinal and total body bone mineral content was measured before the start of the study and after one and two years.

\section{MEASUREMENT OF BONE TURNOVER}

Blood samples were taken and urine was collected in the morning after an overnight fast and abstinence from tobacco. Serum alkaline phosphatase activity was measured enzymatically ${ }^{20}$; plasma bone Gla protein concentration was measured by radioimmunoassay ${ }^{21}$; fasting urinary calcium and creatinine concentrations were measured with an autoanalyser; and fasting

Mean (SD) clinical data, bone mineral content, and biochemical estimates of calcium metabolism at start of study in postmenopausal women receiving salcatonin or placebo, not including and including those who left study before it ended at two years

\begin{tabular}{|c|c|c|c|c|}
\hline & \multicolumn{2}{|c|}{ Women receiving salcatonin } & \multicolumn{2}{|c|}{ Women receiving placebo } \\
\hline & $\begin{array}{l}\text { Those who completed } \\
\text { study }(n=19)\end{array}$ & $\begin{array}{l}\text { Those entered into } \\
\text { study }(n=26)\end{array}$ & $\begin{array}{l}\text { Those who completed } \\
\text { study }(n=20)\end{array}$ & $\begin{array}{l}\text { Those entered into } \\
\text { study }(n=26)\end{array}$ \\
\hline Age $($ years $)$ & $52 \cdot 2(2 \cdot 6)$ & $52 \cdot 3(2 \cdot 6)$ & $52.9(1.8)$ & $52.9(1.5)$ \\
\hline Menopausal age (months) & $42(11)$ & $42(10)$ & $41(11)$ & $42(11)$ \\
\hline Height $(\mathrm{cm})$ & $162 \cdot 3(6 \cdot 1)$ & $163 \cdot 1(6 \cdot 8)$ & $162 \cdot 4(5 \cdot 4)$ & $162 \cdot 4(5 \cdot 3)$ \\
\hline Weight $(\mathrm{kg})$ & $64 \cdot 8(13 \cdot 9)$ & $63 \cdot 5(13 \cdot 0)$ & $62 \cdot 6(8 \cdot 0)$ & $65 \cdot 6(10 \cdot 5)$ \\
\hline $\begin{array}{l}\text { Proximal bone mineral } \\
\text { content (units) }\end{array}$ & $36 \cdot 7(6 \cdot 1)$ & $37 \cdot 3(6 \cdot 2)$ & $36 \cdot 5(5 \cdot 4)$ & $37 \cdot 1(4 \cdot 9)$ \\
\hline $\begin{array}{l}\text { Distal bone mineral } \\
\text { content (units) }\end{array}$ & $36 \cdot 6(7 \cdot 4)$ & $37 \cdot 1(7 \cdot 3)$ & $34 \cdot 8(4 \cdot 9)$ & $35 \cdot 3(5 \cdot 2)$ \\
\hline $\begin{array}{l}\text { Bone mineral content in } \\
\text { lumbar spine }(\mathrm{g})\end{array}$ & $38 \cdot 8(6 \cdot 5)$ & $41 \cdot 0(6 \cdot 4)$ & $39 \cdot 0(5 \cdot 8)$ & $38 \cdot 9(5 \cdot 2)$ \\
\hline $\begin{array}{l}\text { Total skeleton bone } \\
\text { mineral content }(\mathrm{g}) \\
\text { Serum alkaline }\end{array}$ & $2921(493)$ & $3120(505)$ & $2777(380)$ & $2976(358)$ \\
\hline $\begin{array}{l}\text { phosphatase (U/l) } \\
\text { Plasma bone Gla }\end{array}$ & $203(57)$ & $195(57)$ & $206(58)$ & $205(55)$ \\
\hline protein $(\mu \mathrm{g} / \mathrm{l})$ & $11 \cdot 9(4 \cdot 8)$ & $11 \cdot 6(5 \cdot 1)$ & $14 \cdot 6(8 \cdot 0)$ & $14 \cdot 4(9 \cdot 3)$ \\
\hline $\begin{array}{l}\text { creatinine }(\mathrm{mmol} / \mathrm{mol})^{\star} \\
\text { Ratio of calcium to }\end{array}$ & $15 \cdot 8(5 \cdot 2)$ & $14 \cdot 7(5 \cdot 0)$ & $15 \cdot 9(4 \cdot 0)$ & $15 \cdot 6(3 \cdot 7)$ \\
\hline creatinine $(\mathrm{mmol} / \mathrm{mol})^{\star}$ & $0.37(0.22)$ & $0.37(0.22)$ & $0.45(0.18)$ & $0.42(0.21)$ \\
\hline
\end{tabular}

$p>0.05$ for all comparisons by Student's $t$ test for unpaired data.

${ }^{\star}$ Fasting urinary concentrations. urinary hydroxyproline concentration by spectrophotometry. ${ }^{22}$ Values for urinary calcium and hydroxyproline concentrations were corrected for excretion of creatinine.

\section{STATISTICAL EVALUATION}

The size of the sample ( 52 women) was calculated according to the formula given by Kirkwood..$^{23}$ Accordingly, it would require about 44 patients to detect a difference of $4 \%$ between two groups by the technique with the highest precision error (measuring the bone mineral content of the lumbar spine). ${ }^{24}$ The precision errors were given as the coefficients of variation of duplicated measurements calculated by the formula:

coefficient of variation $(\%)=\sqrt{\frac{\Sigma \mathrm{d}^{2}}{2 \mathrm{n}}} \times 100 \% / \frac{\overline{\mathrm{x}}_{1}+\overline{\mathrm{x}}_{2}}{2}$

where $n$ is the number of paired observations and $d$ the difference between two paired measurements $x_{1}$ and $x_{2}$. The measurements were performed in 10 healthy young women..$^{25}$

As changes in bone mineral content and biochemical estimates of bone turnover (expressed as percentages of initial measurements) seemed to be distributed normally we used parametric statistics. The differences between initial values were tested by Student's $t$ test for unpaired data. The initial values were set at $100 \%$ and all subsequent measurements were expressed as a percentage of these values. The significance of changes within groups was assessed by Student's $t$ test for paired data. We used linear regression analysis to calculate the slope of the measurements of bone mass and biochemical estimates of bone turnover against time for each woman. The mean slopes were used in Student's $t$ test for unpaired data to assess differences between groups.

\section{Results}

The table gives the women's clinical data, baseline bone mineral content, and biochemical indicators of calcium metabolism. The data indicate that the women receiving the active drug were well matched with those receiving placebo and that the mean values of all of the variables were similar whether or not the women who left the study were included.

Figure 1 shows the mean changes in spinal bone mineral content during the study. In women receiving salcatonin bone mineral content increased by $2.5 \%$, whereas in women receiving placebo it declined by $5.7 \%(\mathrm{p}<0.001)$. Spinal bone mineral content was higher in those receiving salcatonin than in those receiving placebo both after one year $(p<0.05)$ and after two years $(\mathrm{p}<0.001)$ : after one year the difference was $3 \cdot 8 \%(95 \%$ confidence interval 0.0 to $7 \cdot 6 \%)$ and after two years it was $8 \cdot 2 \%(3 \cdot 8$ to $12 \cdot 6 \%)$.

The mean bone mineral content in the forearms (distal and proximal) and total skeleton of both women receiving salcatonin and those receiving placebo decreased by about $2 \%$ a year (fig 2 ). After two years there were no significant differences in bone mineral content between the two groups at these sites.

Figure 3 shows the mean changes in the biochemical indicators of bone formation and bone resorptionnamely, serum alkaline phosphatase activity, plasma bone Gla protein concentration and fasting urinary calcium and hydroxyproline concentrations corrected for excretion of creatinine. There were no significant differences between the women receiving salcatonin and those receiving placebo in the changes in any of these four variables.

During treatment there were no changes in safety

\section{$\underset{2}{\infty}$ .

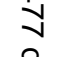

\section{.}

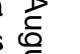
.

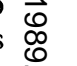
tong 

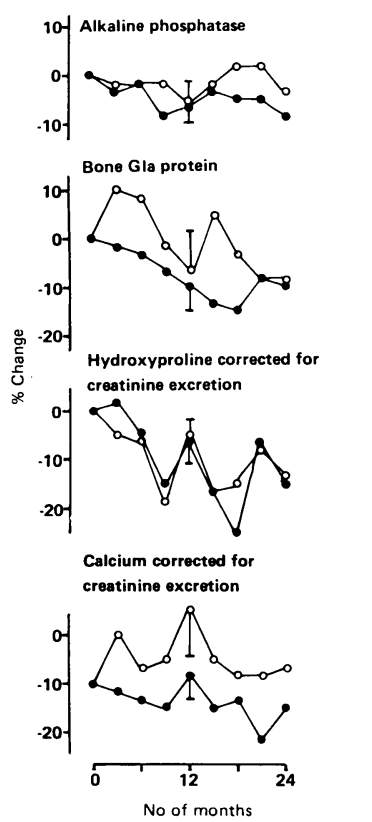

FIG 3-Mean (SEM) changes in biochemical indicators of bone turnover over two years in postmenopausal women treated with salcatonin $(n=19)$ or placebo $(n=20)$ variables - that is, blood pressure, serum creatinine concentration, serum aspartate aminotransferase activity, haemoglobin concentration, leucocyte count, ratio of calcium to protein concentrations, and fasting blood glucose concentration.

\section{Discussion}

The study group was a representative sample of healthy early postmenopausal women. Morphology, bone mass, and biochemical estimates of bone turnover were similar in the women who completed the study and those who did not. The methods used in the study are well established in our laboratory and have precision errors sufficiently low for them to detect clinically relevant changes in calcium metabolism of groups of subjects. ${ }^{1+}$ These facts, and the double blind, placebo controlled design of the study, validate our results.

We found that $100 \mathrm{IU}$ of salcatonin given intranasally had a selective effect by preventing bone loss from the spine but not from the forearms or the total skeleton. Reginster et al also found that salcatonin prevented spinal bone loss, but they did not measure its effect on bone mineral content in other parts of the skeleton. ${ }^{12}$ Treatment with oestrogen, on the other hand, prevents bone loss throughout the skeleton. ${ }^{26}$ Some studies have shown that other agents affect the skeleton selectively: very large calcium supplements affect bone loss from sites composed mainly of cortical bone ${ }^{14}$ and fluoride affects mainly the spinal bone mineral content in patients with established osteoporosis. ${ }^{27}$

Bone loss during the early postmenopause is a general phenomenon and affects all parts of the skeleton. ${ }^{26}$ Cross sectional ${ }^{28}$ and longitudinal studies with quantitative computed tomography, which measures the trabecular bone content exclusively, ${ }^{29}$ however, have shown that bone loss from the spine exceeds that from peripheral bones, at least during the early postmenopausal years. The lumbar spine bears weight, and many women with osteoporosis present with one or more spinal crush fractures; it is therefore of special clinical relevance. But as bone loss affects all parts of the skeleton prevention at all sites is certainly preferable. The selective effect of salcatonin given intranasally on the spine and the lack of a detectable effect on the biochemical indicators of calcium metabolism suggest that the dose of salcatonin may have been too low. Theoretically, a small but undetectable decrease in bone resorption would lead to a slowing down of bone loss. This might particularly be the case in the spine, where the bone turnover and thus the difference between bone formation and bone resorption are high. This suggests that a higher dose would prevent bone loss throughout the skeleton. Other studies have shown an effect of $100 \mathrm{IU}$ of salcatonin given by injection in preventing bone loss at sites other than the spine (the forearm and total body calcium concentration), ${ }^{30}{ }^{31}$ but the bioavailability of salcatonin given intranasally is low: results of a study on the preparation used in the present study showed a bioavailability of about $40 \%{ }^{32}$

We conclude that giving 100 IU salcatonin intranasally to healthy early postmenopausal women affects calcium metabolism and prevents bone loss in the spine and that higher doses may have an effect in other parts of the skeleton.
We thank Sandoz for the salcatonin and calcium.

1 Lindsay R, Hart DM, Aitken JM, MacDonald EB, Anderson JB, Clarke AC. Long-term prevention of postmenopausal osteoporosis by oestrogen. Lance 1976;i:1038-41.

2 Christiansen C, Christensen MS, McNair P, Hagen C, Stocklund K-E, Transbøl I. Prevention of early postmenopausal bone loss: controlled 2-year study in 315 normal females. Eur $\mathcal{F}$ Clin Invest 1980;10:273-9.

3 Ettinger B, Genant HK, Cann CE. Long-term estrogen replacement therapy prevents bone loss and fractures. Ann Intern Med 1985;102:319-24

4 Kiel DP, Felson DT, Anderson JJ, Wilson PWF, Moskowitz MA. Hip fracture and the use of estrogens in postmenopausal women. The Framingham study. $N$ Engl f Med 1987;317:1169-74.

5 Stevenson JC, Abeyasekera G, Hillyard CJ, et al. Regulation of calcium regulating hormones by exogenous sex steroids in early postmenopause. Eur fClin Invest 1983;13:481-7.

6 Greenberg C, Kukreja SC, Bowser EN, Hargis GK, Henderson WJ, Williams GA. Effects of estradiol and progesterone on calcitonin secretion. Endocrinology 1986;118:2594-8.

7 Selby PL, Peacock M. The effect of transdermal oestrogen on bone, calcium regulating hormones and liver in postmenopausal women. Clin Endocrinol (Oxf) 1986;25:543-7.

8 Heath H III, Tiegs RD, Hurley DL. Is inhibition of bone resorption by estrogen or calcium mediated by increased calcitonin secretion? In Christiansen C, Johansen JS, Riis BJ, eds. Osteoporosis 1987. Proceedings of the international symposium on osteoporosis, Aalborg, Denmark. Copenhagen Osteopress, 1987:840-3.

9 Singer FR, Melvin KEW, Mills BG. Acute effects of calcitonin on osteoclasts in man. Clin Endocrinol (Oxf) 1976;5:333-40.

10 Civitelli R, Gonnelli S, Zacchei F, et al. Bone turnover in postmenopausal osteoporosis. $\mathcal{F}$ Clin Invest 1988;82:1268-74.

11 Overgaard K, Riis BJ, Christiansen C, Pødenphant J, Johansen JS. Nasal calcitonin for treatment of established osteoporosis. Clin Endocrinol (Oxf) 1989;30:435-42.

12 Reginster JY, Denis D, Albert A, et al. 1-year controlled randomised trial of prevention of early postmenopausal bone loss by intranasal calcitonin. Lancet 1987 ;ii: $1481-3$.

13 MacIntyre I, Stevenson JC, Whitehead MI, Wimalawansa SJ, Banks LM, Healy MJR. Calcitonin for prevention of postmenopausal bone loss. Lancel $1988 ; \mathrm{i}: 900-2$

14 Riis BJ, Thomsen K, Christiansen C. Does calcium supplementation prevent postmenopausal bone loss? A double-blind, controlled clinical study N Engl F Med 1987;316:173-7.

15 Riis BJ, Thomsen K, Christiansen C. Does 24R, $25(\mathrm{OH})_{2}$-vitamin $\mathrm{D}_{3}$ prevent postmenopausal bone loss? Calcif Tissue Int 1986;39:128-32.

16 Nilas L, Nørgaard H, Pødenphant J, Gotfredsen A, Christiansen C. Bone composition in the distal forearm. Scand J Clin Lab Invest 1987:47:41-6.

17 Nilas L, Borg J, Gotfredsen A, Christiansen C. Comparison of single- and dual-photon absorptiometry in postmenopausal bone mineral loss. $7 \mathrm{Nucl}$ Med 1985;26:1257-62.

18 Gotfredsen A, Borg J, Christiansen C, Mazess RB. Total body bone mineral in vivo by dual photon absorptiometry. I. Measurement procedures. Clin Physiol 1984:4:343-55.

19 Mazess RB. Noninvasive bone measurements. Skeletal Research 1983;2:277 343.

20 Committee on Enzymes of the Scandinavian Society for Clinical Chemistry and Clinical Physiology. Recommended methods for the determination of four enzymes in blood. Scand f Clin Lab Invest 1974;33:291-306.

21 Johansen JS, Mølholm Hansen JE, Christiansen C. A radioimmunoassay for bone Gla protein (BGP) in human plasma. Acta Endocrinol 1987;114:410-6.

22 Pødenphant J, Larsen N-E, Christiansen C. An easy and reliable method for determination of urinary hydroxyproline. Clin Chim Acta 1984;142:145-8.

23 Kirkwood BR. Essentials of medical statistics. Oxford: Blackwell, 1988:191200.

24 Riis BJ, Christiansen C. Measurement of spinal or peripheral bone mass to estimate early postmenopausal bone loss? Am $\mathcal{J}$ Med 1988;84:646-53.

25 Nilas L, Hassager C, Christiansen C. Long-term precision of dual photon absorptiometry in the lumbar spine in clinical settings. Bone and Mineral 1988;3:305-15.

26 Riis BJ, Christiansen C. Measurement of spinal or peripheral bone mass to estimate early postmenopausal bone loss. Am F Med 1988;84:646-53.

27 Riggs BL, Hodgson SF, Muhs J, Wahner HW. Fluoride treatment of osteoporosis: clinical and bone densitometric responses. In: Christiansen C Johansen JS, Riis BJ, eds. Osteoporosis 1987. Proceedings of the international symposium on osteoporosis, Aalborg, Denmark. Copenhagen: Osteopress, 1987:817-23.

28 Riggs BL, Wahner HW, Dunn WL, Mazess RB, Offord KP, Melton LJ III. Differential changes in bone mineral density of the appendicular and axial skeleton with aging. Relationship to spinal osteoporosis. $\mathcal{f}$ Clin Invest 1981;67:328-35.

29 Genant HK, Cann CE, Ettinger B, Gordan GS. Quantitative computed tomography of vertebral spongiosa: a sensitive method for detecting early bone loss after oophorectomy. Ann Intern Med 1982;97:699-705.

30 Mazzuoli GF, Passeri M, Gennari C, et al. Effects of salmon calcitonin in postmenopausal osteoporosis: a controlled double-blind clinical study. postmenopausal osteoporosis:

31 Gruber HE, Ivey JL, Baylink DJ, et al. Long-term calcitonin therapy in postmenopausal osteoporosis. Metabolism 1984;33:295-303.

32 Boerlin V, Nüesch E, Schmid AC, Rosenthaler J. Bioavailability study with salmon-calcitonin (SMC 20-051) in man (intramuscular injection vs intranasal administrations). Basle: Pharmaceutical Division of Sandoz, 1983.

(Accepled 14 fune 1989) 